\title{
PENGARUH GOOD CORPORATE GOVERNANCE TERHADAP KINERJA PASAR PERUSAHAAN YANG DIMEDIASI OLEH PENGUNGKAPAN LAPORAN KEBERLANJUTAN
}

\author{
Stefanie Salim \\ Megawati Oktorina \\ Universitas Katolik Atma Jaya \\ steff0129@gmail.com
}

\begin{abstract}
This study aimed to analyze the influence of the Good Corporate Governance $(G C G)$ on the market performance that is mediated by the disclosure of sustainability report. This study used two model which first model aims to obtain empirical evidence about the influence of GCG and the disclosure of sustainability reporting on market performance. The second model aimed to get empirical evidence whether disclosure of the sustainability report is able to mediate the relationship between GCG and market performance.

This study uses multiple linear regression model to test the hypothesis in the first and second research model. The sample in this study is a non-financial company participant Indonesia Sustainability Report Awards (ISRA) 2009-2012 listed in the Indonesia Stock Exchange. In the first research model using 30 samples, while the second models using 29 samples.

The results showed that the GCG as measured by the number of meetings of the board of directors and the proportion of independent board have a significant effect on the market performance. However, GCG as measured by governance committee did not prove the existence of an effect on the market performance. In addition, the disclosure of sustainability reports proved positive significant effect on the market performance. The results also found that disclosure of the sustainability report is able to mediate the relationship between GCG and market performance.
\end{abstract}

Keywords: Good Corporate Governance, Sustainability Report, Market Performance, Price-to-Book Value

\section{PENDAHULUAN}

Corporate Governance merupakan konsep yang dikembangkan untuk mencegah terjadinya konflik kepentingan. Penerapan corporate governance diharapkan dapat memupuk rasa percaya para investor bahwa mereka akan memperoleh keuntungan atas investasi yang mereka lakukan. Ramdiani dan Yadnyana (2013) menyatakan bahwa penerapan corporate governance berpengaruh signifikan terhadap kenaikan harga saham perusahaan.

Penerapan corporate governance terwujud dalam program Corporate Social Responsbility (CSR) perusahaan. Dalam Pedoman Umum Good Corporate Governance Indonesia (2006) disebutkan bahwa melalui penerapan corporate 
governance, perusahaan diharapkan dapat merealisasikan tanggung jawab sosialnya demi menjaga kelangsungan hidup perusahaan. Melalui pelaksanaan CSR, perusahaan dapat menunjukkan kepada masyarakat keseriusan perusahaan dalam menanggapi isu terkait aspek sosial dan lingkungan. Selain itu, penerapan indeks yang memasukkan kategori saham perusahaan yang telah mempraktikkan CSR oleh otoritas bursa saham di dunia memacu investor global untuk berinvestasi pada perusahaan-perusahaan yang sudah masuk dalam indeks tersebut. Sebagai dampaknya, perusahaan mulai dengan serius melakukan tanggung jawab sosialnya dan kemudian melakukan pengungkapan atas aktivitas sosialnya dalam laporan tahunan perusahaan atau dalam satu paket pelaporan terpisah yang dikenal sebagai laporan keberlanjutan (sustainability report).

Di Indonesia, pelaksanaan tanggung jawab sosial perusahaan bersifat wajib atau mandatori. Hal tersebut tertuang dalam dua pasal yang terdapat pada Undang-Undang No.40 Tahun 2007 tentang Perseroan Terbatas. Akan tetapi, hingga saat ini belum ada peraturan yang memuat tentang ketentuan pengungkapan tanggung jawab sosial secara terpisah sebagai laporan keberlanjutan sehingga pelaporan keberlanjutan di Indonesia masih bersifat sukarela (voluntary disclosure). Namun demikian, pengungkapan CSR melalui laporan keberlanjutan terus mengalami peningkatan dari waktu ke waktu. Sejak tahun 2005, sebagai bentuk apresiasi kepada perusahaan-perusahaan di tanah air yang telah secara sukarela menerbitkan laporan keberlanjutan, Ikatan Akuntan Indonesia (IAI) bersama National Center for Sustainability Reporting (NCSR) menggelar sebuah ajang penghargaan yang diberi nama Indonesia Sustainability Reporting Awards (ISRA).

Pengungkapan CSR sejalan dengan dua prinsip utama Good Corporate Governance (GCG) yaitu transparansi dan akuntabilitas sehingga dianggap sebagai konsekuensi logis dari implementasi GCG. Informasi yang tersaji dalam laporan keberlanjutan merupakan bukti bahwa perusahaan telah turut serta membantu memecahkan permasalahan terkait risiko dan ancaman terhadap keberlanjutan tidak hanya dalam lingkup ekonomi, tetapi juga sosial dan lingkungan (GRI, 2006). Oleh karena itu, pelaporan keberlanjutan dapat digunakan oleh investor sebagai bahan pertimbangan untuk berinvestasi terutama dalam lingkup sustainable and responsible investment.

Penelitian ini bertujuan untuk memperoleh bukti empiris mengenai pengaruh penerapan GCG dan pengungkapan laporan keberlanjutan terhadap kinerja pasar perusahaan, serta bertujuan untuk membuktikan bahwa pengungkapan laporan keberlanjutan mampu memediasi hubungan antara GCG dan kinerja pasar perusahaan. Melalui penelitian ini, peneliti berharap dapat memberikan kontribusi yaitu (1) bagi pemerintah, IAI, dan pihak lain yang memiliki otoritas sebanding, sebagai penyedia informasi dan bahan pengambil kebijakan mengingat belum adanya peraturan yang mengatur pelaksanaan pengungkapan CSR dalam laporan keberlanjutan di Indonesia, (2) dan bagi penelitian mengenai GCG dan pengungkapan laporan keberlanjutan agar dapat menjadi bahan referensi bagi penelitian di masa yang akan datang terkait topik implementasi GCG dan pelaporan keberlanjutan di Indonesia.

\section{REVIEW LITERATUR DAN HIPOTESIS}

\section{Agency Theory}

Hubungan keagenan dalam teori keagenan tercipta akibat adanya kontrak antara pemberi wewenang (principal) dan penerima wewenang (agent). Dalam hal ini, prinsipal memberikan otoritas pengambilan keputusan kepada agen dalam mengelola perusahaan (Jensen \& Meckling 1976).

Dalam hubungan keagenan, prinsipal dan agen terkadang memiliki tujuan yang berbeda yang menyebabkan munculnya konflik kepentingan. Selain itu, terdapat juga masalah asimetris informasi (information asymmetric) yang timbul akibat 
minimnya informasi mengenai perusahaan yang didapat oleh pemilik perusahaan atau pemegang saham. Sebagai pengelola perusahaan, manajer cenderung mengetahui lebih banyak informasi mengenai kondisi perusahaan dibandingkan pemilik perusahaan atau pemegang saham, namun terkadang manajer menyampaikan tidak seluruh informasi yang diketahuinya (Hendriksen \& Van Breda, dalam Waryanto 2010).

Corporate Governance merupakan konsep yang didasarkan pada teori keagenan. Konsep ini diharapkan mampu menjadi alat yang dapat memberikan keyakinan kepada para investor bahwa manajer perusahaan tidak akan mengalokasikan dana yang mereka tanamkan ke dalam proyekproyek yang dapat merugikan mereka.

\section{Stakeholder Theory}

Phillips (2011) mendefinisikan stakeholder sebagai sekelompok orang yang dapat mempengaruhi dan/atau dipengaruhi oleh aktivitas perusahaan. Oleh karena itu, perusahaan diharapkan untuk menjalankan kegiatan bisnisnya tidak hanya demi kepentingannya sendiri, namun juga mampu memberikan manfaat bagi stakeholdernya. Stakeholder dalam hal ini meliputi pemegang saham, karyawan, kreditur, pelanggan, pemasok, dan masyarakat.

Stakeholder theory merupakan dasar dari pengungkapan laporan keberlanjutan. Pengungkapan laporan keberlanjutan dianggap sebagai wujud nyata atas upaya perusahaan dalam menciptakan hubungan yang harmonis dengan stakeholder perusahaan. Dengan pengungkapan ini, perusahaan diharapkan mampu memenuhi kebutuhan informasi perihal kinerja ekonomi, sosial dan lingkungannya agar mendapatkan dukungan dari para stakeholder yang berpengaruh terhadap kelangsungan hidup perusahaan.

\section{Legitimacy Theory}

Secara umum, teori legitimasi digunakan untuk menganalisis perilaku organisasi. Ghozali dan Chariri (2007) mengartikan teori legitimasi sebagai suatu kondisi atau status yang muncul ketika suatu sistem nilai perusahaan sejalan dengan sistem nilai dari sistem sosial yang lebih besar dimana perusahaan tersebut menjadi bagiannya, sehingga apabila perusahaan memiliki sistem nilai yang berbeda secara nyata atau potensial maka akan muncul ancaman terhadap legitimasi perusahaan.

Teori legitimasi merupakan dasar dari konsep CSR. Menurut teori ini, kegiatan operasional perusahaan hanya dapat berjalan apabila perusahaan memperoleh izin dari masyarakat. Dalam konteks ini, CSR dipandang sebagai perjanjian antara perusahaan dengan masyarakat. Perusahaan setuju untuk tidak melakukan halhal yang dapat merugikan masyarakat walaupun hal-hal tersebut akan memberikan keuntungan bagi perusahaan. Sebagai dampaknya, apabila perusahaan melakukan kegiatan yang bertentangan dengan komitmen perusahaan dalam pelaksanaan tanggung jawab sosialnya, hal tersebut dapat menjatuhkan citra perusahaan dan menurunkan simpati masyarakat terhadap perusahaan yang mengakibatkan hancurnya legitimasi perusahaan.

\section{Corporate Governance}

Menurut Malaysian High Level Finance Committee on Corporate Governance (Purba, 2011), Corporate Governance merupakan proses dan struktur yang digunakan oleh perusahaan untuk menentukan kebijakan dalam rangka meningkatkan keberhasilan usaha dan akuntabilitas perusahaan demi meningkatkan nilai tambah bagi pemegang saham dengan turut memperhatikan kepentingan para stakeholder perusahaan.

Istilah corporate governance pertama kali diperkenalkan oleh Cadbury Committee (1992) yang menggunakan istilah tersebut dalam laporan mereka yang dikenal dengan nama Cadbury Report. Melalui isi dari Cadbury Report dapat didefinisikan bahwa corporate governance adalah suatu prinsip yang mengarahkan dan mengendalikan perusahaan guna mencapai keseimbangan antara kekuatan dan 
kewenangannya dalam memberikan pertanggungjawabannya baik kepada para pemegang saham maupun pemangku kepentingan lainnya (Che Haat, dalam Arifin 2010).

Corporate governance dibutuhkan untuk menciptakan pasar yang efisien, transparan, konsisten, dan sesuai dengan peraturan perundangundangan. Dalam penerapannya, corporate governance perlu didukung oleh tiga pilar yang saling berhubungan, yaitu negara sebagai regulator, dunia usaha sebagai pelaku pasar, dan masyarakat sebagai konsumen. Menurut Pedoman Umum Good Corporate Governance Indonesia yang disusun oleh Komite Nasional Kebijakan Governance (KNKG) tahun 2006, terdapat lima prinsip utama yang terkandung dalam GCG, yaitu transparansi, akuntabilitas, responsibilitas, independensi, serta kewajaraan dan kesetaraan.

\section{Laporan Keberlanjutan}

Laporan keberlanjutan memiliki isi dasar yang harus diungkapkan dalam laporan. Isi dasar tersebut berpedoman pada standar pengungkapan yang termuat dalam GRI guidelines. Penelitian ini menggunakan GRI G3 yang terbit pada tahun 2006 sebagai standar pengungkapan laporan keberlanjutan. Menurut GRI G3, laporan keberlanjutan harus memuat strategi dan profil perusahaan, pendekatan manajemen, dan indikator kinerja yang terdiri dari indikator kinerja ekonomi, lingkungan, tenaga kerja dan pekerjaan yang layak, hak asasi manusia, masyarakat, dan tanggung jawab produk. Di samping itu, pengungkapan laporan keberlanjutan yang sesuai dengan GRI (Global Reporting Index) memiliki prinsip-prinsip yang tercantum dalam GRI-G3 Guidelines, yaitu keseimbangan, dapat diperbandingkan, kecermatan, ketepatan waktu, kejelasan, dan keterandalan.

\section{Kinerja Pasar}

Kinerja pasar perusahaan merupakan reaksi investor terhadap saham perusahaan di pasar modal. Reaksi tersebut muncul apabila terdapat informasi yang memberikan nilai guna bagi investor untuk melakukan transaksi di pasar modal. Dalam hal ini, investor percaya atas prospek perusahaan ke depan. Persepsi investor terhadap perusahaan dapat dilihat melalui harga saham perusahaan yang merupakan cerminan dari nilai perusahaan. Apabila nilai perusahaan tinggi maka kinerja pasar perusahaan baik. Menurut Kelana dan Wijaya dalam Nurdin dan Cahyandito (2006), aspek kepercayaan dari investor merupakan salah satu aspek yang memiliki pengaruh paling besar terhadap kinerja pasar perusahaan.

Ada beberapa cara yang dapat digunakan untuk mengukur kinerja pasar perusahaan, salah satunya adalah dengan menghitung price to book value $(P B V)$. PBV merupakan perbandingan antara harga pasar saham dengan nilai buku per saham (Brigham \& Houston 2009).

\section{Pengembangan Hipotesis}

\section{Pengaruh Good Corporate Governance Terhadap Kinerja Pasar Perusahaan}

Sebagai organ perusahaan yang berwenang atas kepengurusan perusahaan, direksi memegang peranan penting dalam penerapan GCG. Direksi bertugas dan bertanggung jawab dalam mengelola perusahaan agar seluruh sumber daya berfungsi maksimal sehingga mampu meningkatkan profitabilitas yang berdampak pada meningkatnya nilai perusahaan secara bersinambungan (Analisis Pelaksanaan Tata Kelola Emiten dan Perusahaan Publik, 2010). Keefektifan kinerja dewan direksi dalam proses pengelolaan perusahaan dapat dilihat melalui rapat dewan direksi. Umumnya, rapat direksi diadakan secara rutin minimum sekali dalam satu bulan. Dalam rapat tersebut, direksi menyusun kebijakan-kebijakan perusahaan dan membahas pemecahan atas masalah-masalah yang tengah dihadapi perusahaan.

Puteri (2013) menyatakan bahwa jumlah dewan direksi berpengaruh positif pada kinerja keuangan perusahaan. Meningkatnya kinerja 
keuangan berdampak langsung pada meningkatnya kinerja pasar perusahaan. Apabila jumlah dewan direksi memberi pengaruh positif terhadap kinerja keuangan perusahaan, jumlah rapat dewan direksi yang merupakan tolok ukur atas efektivitas kinerja direksi seharusnya juga memberikan pengaruh serupa. Berdasarkan hal tersebut, peneliti merumuskan hipotesis berikut:

$\mathbf{H}_{1 \mathbf{a}}$ : Jumlah rapat dewan direksi berpengaruh positif terhadap kinerja pasar perusahaan.

Keberadaan komisaris independen dalam anggota dewan komisaris penting dalam melakukan pengawasan terhadap kinerja direksi. Dengan demikian, semakin besar proporsi komisaris independen, maka peran dewan komisaris sebagai pengendali tindakan direksi akan semakin baik sehingga kinerja perusahaan akan mengalami peningkatan (Puteri 2013). Adapun jumlah minimal komisaris independen yang harus terdapat dalam anggota dewan komisaris perusahaan, yaitu sebesar 30\% dari keseluruhan anggota dewan komisaris seperti yang telah ditetapkan oleh Bursa Efek Indonesia.

Dalam penelitian yang dilakukan oleh Widyati (2013), diperoleh hasil bahwa jumlah komisaris independen memiliki pengaruh positif terhadap kinerja keuangan perusahaan. Meningkatnya kinerja keuangan perusahaan pada umumnya akan diiringi oleh reaksi investor terhadap saham perusahaan di pasar. Berdasarkan hal tersebut, peneliti merumuskan hipotesis berikut:

$\begin{aligned} \mathbf{H}_{\mathbf{1 b}} \text { : } & \text { Proporsi dewan komisaris independen } \\ & \text { berpengaruh terhadap kinerja pasar } \\ & \text { perusahaan. }\end{aligned}$

Pembentukan governance committee dipandang sebagai suatu bentuk usaha perwujudan GCG yang kuat dengan tujuan meningkatkan efektivitas pengawasan dan pengendalian internal perusahaan atas laporan keuangan (Widianto 2011).
Keberadaan governance committee merupakan salah satu cara untuk mengurangi praktik manajemen laba. Penunjukkan anggota governance committee yang kompeten dan berkualitas dapat membantu perusahaan untuk meyakinkan para investor bahwa laporan keuangan yang disajikannya telah mencerminkan kondisi perusahaan yang sesungguhnya. Dengan meningkatnya kepercayaan investor terhadap laporan keuangan perusahaan, kinerja pasar perusahaan diharapkan akan ikut naik. Berdasarkan hal tersebut, dirumuskan hipotesis berikut:
$\mathbf{H}_{1 \mathbf{c}}$ : Keberadaan governance committee berpengaruh terhadap kinerja pasar perusahaan.

\section{Pengaruh Pengungkapan Laporan Keberlanjutan Terhadap Kinerja Pasar Perusahaan}

Pengungkapan laporan keberlanjutan bukan tanpa insentif. Dengan menerbitkan laporan keberlanjutan, perusahaan berharap dapat membentuk citra yang baik di mata para pengguna laporan keberlanjutan sehingga dapat menarik minat para investor untuk berinvestasi. Burhan dan Rahmanti(2012) menyatakan bahwapengungkapan laporan keberlanjutan berpengaruh positif terhadap kinerja keuangan perusahaan. Penelitian serupa yang dilakukan Adhima (2011) juga memperoleh hasil bahwa pengungkapan laporan keberlanjutan yang diproksikan oleh SRDI (sustainability report disclosure index) memiliki pengaruh positif signifikan terhadap profitabilitas perusahaan. Meningkatnya profitabilitas perusahaan diharapkan dapat menarik minat investor untuk berinvestasi. Berdasarkan uraian tersebut, peneliti merumuskan hipotesis berikut:

$\mathbf{H}_{2}$ : Pengungkapan laporan keberlanjutan berpengaruh positif terhadap kinerja pasar perusahaan. 
Pengungkapan Laporan Keberlanjutan Sebagai Variabel Intervening Antara Hubungan Good Corporate Governance dan Kinerja Pasar Perusahaan

Sebagai sarana pelaporan nonkeuangan yang memuat informasi mengenai aktivitas sosial perusahaan, laporan keberlanjutan merupakan cerminan atas pelaksanaan CSR yang menjadi salah satu perhatian utama dalam penerapan GCG. Dengan menerbitkan laporan keberlanjutan, perusahaan telahmemenuhi duaprinsiputama GCG, yaitu transparansi dan akuntabilitas. Pengungkapan laporan keberlanjutan juga telah terbukti memiliki pengaruh positif terhadap kinerja keuangan perusahaan (Burhan \& Rahmanti 2012; Adhima 2011; Susanto \& Tarigan 2013). Apabila kinerja keuangan meningkat, kinerja pasar perusahaan diharapkan akan meningkat. Berdasarkan uraian tersebut, peneliti merumuskan hipotesis berikut:

\section{$\mathbf{H}_{\mathbf{3}}$ : Pengungkapan laporan keberlanjutan memediasi hubungan antara GCG dan kinerja pasar perusahaan.}

\section{METODE PENELITIAN}

\section{Populasi dan Sampel}

Populasi yang digunakan dalam penelitian ini adalah perusahaan-perusahaan yang terdaftar di Bursa Efek Indonesia tahun 2009 - 2012. Pemilihan sampel penelitian menggunakan metode purposive sampling dengan tujuan mendapatkan sampel yang sesuai dengan kriteria yang ditentukan. Kriteria yang digunakan untuk pemilihan sampel adalah sebagai berikut:

1. Perusahaan go public partisipan ISRA 20092012.

2. Perusahaan tidak termasuk perbankan atau lembaga keuangan lainnya.

3. Perusahaan menerbitkan laporan keberlanjutan atau memuat laporan keberlanjutan dalam laporan tahunan perusahaan paling sedikit satu kali selama tahun 2009-2012 dan dipublikasikan melalui website perusahaan.
4. Perusahaan menerbitkan laporan keuangan yang telah diaudit dan laporan tahunan secara kontinyu selama tahun 2009-2012 dan dipublikasikan melalui website Bursa Efek Indonesia maupun website perusahaan.

Berdasarkan kriteria pengambilan sampel di atas maka diperoleh sebanyak 15 perusahaan atau 30 observasi untuk model penelitian pertama dan sebanyak 17 perusahaan atau 29 observasi untuk model penelitian kedua.

\section{Definisi Operasional Variabel dan Pengukuran Variabel}

\section{Kinerja Pasar}

Dalam penelitian ini digunakan kinerja pasar perusahaan sebagai variabel terikat yang diukur dengan menggunakan rasio price to book value yang dinyatakan dengan rumus:

$$
\text { Price to book value }=\frac{\text { Harga pasar perlembar saham }}{\text { Nilai buku perlembar saham }}
$$

Sumber: Tryfino, 2009

Harga pasar yang digunakan adalah harga per akhir periode akuntansi perusahaan dengan asumsi bahwa pengungkapan tersebut mendapat reaksi dari investor di pasar. Nilai buku per lembar saham dihitung dengan cara:

$$
\text { Nilai buku perlembar saham }=\frac{\text { Total ekuitas }}{\text { Jumlah saham beredar }}
$$

Sumber: Tryfino, 2009

\section{Jumlah Rapat Dewan Direksi}

Implementasi GCG melalui dewan direksi diukur dengan menghitung jumlah rapat anggota dewan direksi yang terjadi selama satu tahun. Jumlah rapat dewan direksi menunjukkan tingkat efektivitas komunikasi dan koordinasi antar anggota dewan direksi dalam mewujudkan tata kelola perusahaan yang baik. 


\section{Proporsi Dewan Komisaris Independen}

Proporsi komisaris independen dalam dewan komisaris perusahaan yang dirumuskan sebagai berikut:

$$
\text { Proporsi Komisaris Independen }=\frac{\text { Jumlah komisaris independen }}{\text { Jumlah dewan komisaris perusahaan }}
$$

\section{Keberadaan Governance Committee}

Menurut Willey (2009 diacu dalam Widianto, 2011), governance committee merupakan sebuah komite yang terdiri dari beberapa anggota dewan direksiyang bertugasmengembangkan danmemberi rekomendasi kepada dewan dalam pelaksanaan dan etika corporate governance. Dalam penelitian ini, pelaksanaan corporate governance yang dilakukan perusahaan dilihat dengan keberadaan governance committee. Pengukuran dilakukan dengan variabel dummy yaitu memberikan nilai 1 untuk perusahaan yang membentuk governance committee dan 0 untuk perusahaan yang tidak membentuk governance committee.

\section{Pengungkapan Laporan Keberlanjutan}

Pengungkapan tanggung jawab sosial perusahaan dalam laporan keberlanjutan diukur dengan proksi SRDI (sustainability report disclosure index) berdasarkan pedoman standar pengungkapan laporan keberlanjutan yang dimuat dalam GRI G3. Pengukuran variety dari SRDI menggunakan content analysis yang juga pernah digunakan oleh Soelistyoningrum dan Prastiwi (2011) dalam penelitian serupa. Content analysis merupakan suatu metode pengumpulan data penelitian melalui teknik observasi dan analisis terhadap isi atau pesan dari suatu dokumen.

Pengukuran ini menggunakan pendekatan dikotomi yaitu setiap item SR dalam objek penelitian diberi nilai 1 (satu) jika diungkapkan dan nilai 0 (nol) jika tidak diungkapkan. Setelah itu, skor dari setiap item dijumlahkan untuk memperoleh total skor dari masing-masing perusahaan. Perhitungan SRDI dirumuskan sebagai berikut:

$$
\mathrm{SRDI}_{\mathrm{x}}=\frac{\Sigma_{\mathrm{ix}}}{79^{*}}
$$

Keterangan:

$$
\begin{aligned}
\mathrm{SRDI}_{\mathrm{x}}= & \text { sustainability report disclosure index } \\
& \text { perusahaan } \mathrm{x} \\
\Sigma_{\mathrm{ix}}= & \text { dummy variable: } 1=\text { jika item i } \\
& \text { diungkapkan; } 0=\text { jika item i tidak } \\
& \text { diungkapkan } \\
= & \text { total item yang harus diungkapkan } \\
& \text { berdasarkan GRI G3 }
\end{aligned}
$$

Dengan demikian $0 \leq \operatorname{SRDI}_{\mathrm{x}} \leq 1$

\section{Model Penelitian}

Penelitian ini memiliki dua model. Model pertama menggunakan GCG yang diproksikan oleh jumlah rapat dewan direksi, proporsi dewan komisaris independen, dan keberadaan governance committee serta pengungkapan laporan keberlanjutansebagai variabel independendan kinerja pasar sebagai variabel dependen. Model penelitian kedua menggunakan pengungkapan laporan keberlanjutan sebagai variabel intervening antara hubungan GCG dengan kinerja pasar perusahaan. Berdasarkan hal tersebut, dapat digambarkan model penelitian sebagai berikut:

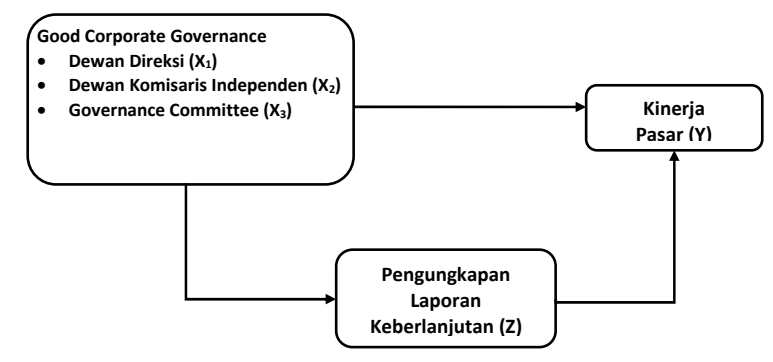

\section{Gambar 1 Model Penelitian}




\section{Metode Analisis Data}

Pengujian hipotesis mengenai pengaruh GCG dan pengungkapan laporan keberlanjutan terhadap kinerja pasar perusahaan menggunakan analisis regresi linear berganda (multiple linear regression), sedangkan pengujian variabel intervening menggunakan uji analisis jalur (path analysis).

\section{HASIL PENELITIAN DAN PEMBAHASAN}

\section{Model Penelitian Pertama}

Model penelitian pertama bertujuan untuk menganalisis pengaruh langsung GCG dan pengungkapan laporan keberlanjutan sebagai variabel independen terhadap kinerja pasar perusahaan. Sebelum dilakukan pengujian regresi linear berganda, telah dilakukan uji asumsi regresi dan hasilnya data berdistribusi normal dan bebas multikolinearitas, bebas autokorelasi, serta homoskedastisitas.

\section{Uji Statistik $\mathbf{F}$}

Berdasarkan Tabel 1, diketahui bahwa model tersebut memiliki nilai $\mathrm{F}$ sebesar 3.655 dengan tingkat signifikansi sebesar 0.018. Dengan membandingkan nilai probabilitas ( $p$ value) dengan tingkat signifikansi yang telah ditetapkan sebelumnya yaitu sebesar 0.1, maka dapat disimpulkan bahwa model penelitian ini memenuhi syarat (Fit Model). Hal ini karena nilai signifikansi model penelitian yaitu 0.018 atau $0.18 \%$ lebih kecil dari tingkat signifikansi yang ditetapkan dalam penelitian ini yaitu 0.1 atau $10 \%$. Dengan demikian, dapat disimpulkan bahwa jumlah rapat dewan direksi, proporsi dewan komisaris independen, keberadaan governance committee, dan pengungkapan laporan keberlanjutan secara bersama-sama berpengaruh terhadap kinerja pasar perusahaan.
Tabel 1

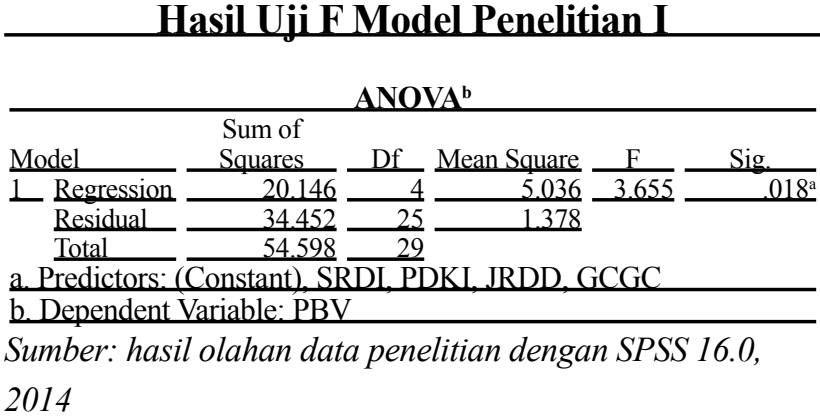

\section{Uji Statistik t}

Tabel 2 menunjukkan hasil uji t untuk model penelitian pertama. Pada tabel tersebut dapat dilihat bahwa variabel jumlah rapat dewan direksi (JRDD) memiliki nilai signifikansi sebesar 0.072 (dilihat pada kolom Sig.) dan memiliki arah positif (dilihat pada kolom Unstandardized Coefficients $\beta$ ). Hal ini berarti variabel jumlah rapat dewan direksi memiliki pengaruh signifikan terhadap kinerja pasar karena nilai signifikansinya lebih kecil daripada taraf signifikansi yang ditetapkan dalam penelitian ini yaitu 0.1 atau $10 \%$. Dengan demikian, $\mathrm{H}_{1 \mathrm{a}}$ diterima sebab hasil uji t menunjukkan bahwa variabel jumlah rapat dewan direksi terbukti berpengaruh terhadap kinerja pasar.

Demikian juga dengan variabel proporsi dewan komisaris independen (PDKI) dan variabel pengungkapan laporan keberlanjutan (SRDI). Hasil uji t untuk kedua variabel tersebut menunjukkan tingkat signifikansi sebesar 0.056 untuk variabel proporsi dewan komisaris independen dan tingkat signifikansi 0.014 untuk variabel pengungkapan laporan keberlanjutan dengan arah positif untuk masing-masing variabel. Hal ini berarti variabel proporsi dewan komisaris independen dan variabel pengungkapan laporan keberlanjutan memiliki pengaruh signifikan positif terhadap kinerja pasar. Dengan demikian $\mathrm{H}_{1 \mathrm{~b}}$ dan $\mathrm{H}_{2}$ diterima sebab hasil uji t menunjukkan bahwa variabel proporsi dewan komisaris independen dan pengungkapan laporan 
keberlanjutan terbukti memiliki pengaruh yang signifikan terhadap kinerja pasar.

Berbeda dengan ketiga variabel sebelumnya, berdasarkan hasil uji t, variabel keberadaan governance committee memiliki tingkat signifikansi sebesar 0.102 . Hal ini berarti variabel keberadaan governance committee tidak terbukti berpengaruh signifikan terhadap kinerja pasar karena nilai signifikansinya lebih besar daripada taraf signifikansi yang ditetapkan dalam penelitian ini yaitu 0.1 atau $10 \%$. Dengan demikian, $\mathrm{H}_{1 \mathrm{c}}$ ditolak sebab hasil uji t membuktikan bahwa keberadaan governance committee tidak terbukti memiliki pengaruh yang signifikan terhadap kinerja pasar.

Tabel 2

Hasil Uji t Model Penelitian I

\begin{tabular}{|c|c|c|c|c|c|}
\hline \multicolumn{6}{|c|}{ Coefficients $^{\mathrm{a}}$} \\
\hline \multirow[t]{2}{*}{ Model } & $\begin{array}{r}\text { Unstand } \\
\text { Coeffi }\end{array}$ & $\begin{array}{l}\text { dized } \\
\text { ents }\end{array}$ & $\begin{array}{l}\text { Standardized } \\
\text { Coefficients }\end{array}$ & \multirow{2}{*}{$t$} & \multirow{2}{*}{ Sig. } \\
\hline & Std. & Beta & & & \\
\hline 1 (Constant) & -4.778 & 2.169 & & -2.203 & .037 \\
\hline JRDD & .033 & .017 & .337 & 1.878 & .072 \\
\hline PDKI & 6.846 & 3.417 & .348 & 2.004 & .056 \\
\hline GCGC & -.914 & .538 & -.338 & -1.698 & .102 \\
\hline SRDI & 4.993 & 1.886 & .533 & 2.647 & .014 \\
\hline
\end{tabular}

a. Dependent Variable: PBV

Sumber: hasil olahan data penelitian dengan SPSS 16.0,

2014

\section{Model Penelitian Kedua}

Model penelitian kedua bertujuan untuk menganalisis menganalisis pengaruh pengungkapan laporan keberlanjutan sebagai variabel pemediasi antara hubungan GCG dan kinerja pasar perusahaan. Sebelum dilakukan pengujian regresi linear berganda, telah dilakukan uji asumsi regresi dan hasilnya data berdistribusi normal dan bebas multikolinearitas, bebas autokorelasi, serta bebas heteroskedastisitas.

\section{Uji Analisis Jalur}

Dalam penelitian ini, hubungan antara variabel GCG dengan variabel kinerja pasar perusahaan dimediasi oleh variabel pengungkapan laporan keberlanjutan. Logikanya, semakin baik mekanisme GCG dalam suatu perusahaan akan meningkatkan kualitas pengungkapan laporan keberlanjutan sehingga akan turut meningkatkan kinerja pasar perusahaan.

Pada Tabel 3 dan Tabel 4 menunjukkan bahwa satu-satunya komponen GCG yang memiliki nilai signifikansi yang konsisten hanya proporsi dewan komisaris independen (PDKI) sehingga dalam penghitungan koefisien jalur hanya akan digunakan nilai koefisien yang dimiliki proporsi dewan komisaris independen untuk mewakili GCG.

Berdasarkan Tabel 3, diketahui bahwa nilai standardized beta proporsi dewan komisaris independen (PDKI) sebesar -0.576 dan signifikan pada 0.001 yang berarti proporsi dewan komisaris independen mempengaruhi pengungkapan laporan keberlanjutan (SRDI). Nilai koefisien standardized beta -0.576 merupakan nilai path atau jalur P2 pada Gambar 3.

Berdasarkan Tabel 4, diketahui bahwa nilai standardized beta untuk proporsi dewan komisaris independen sebesar -0.607 dengan tingkat signifikansi 0.000 dan pengungkapan laporan keberlanjutan (SRDI) sebesar 0.463 dengan tingkat signifikansi 0.011. Nilai koefisien standardized beta-0.607 merupakan nilai path atau jalur P1 dan nilai koefisien standardized beta 0.463 merupakan nilai path atau jalur P3 pada Gambar 2.

\section{Tabel 3}

\section{Pengujian Path Analysis Model Penelitian II untuk Pengaruh GCG Terhadap Pengungkapan Laporan Keberlanjutan}

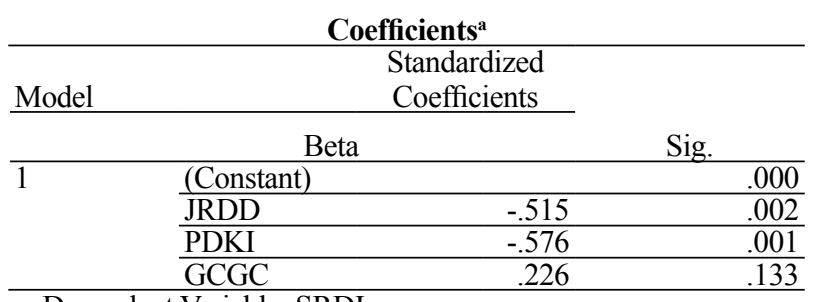

a. Dependent Variable: SRDI

Sumber: hasil olahan data penelitian dengan SPSS 16.0, 2014 
Tabel 4

Pengujian Path AnalysisModel Penelitian II untuk Pengaruh GCG dan Pengungkapan Laporan Keberlanjutan Terhadap Kinerja Pasar Perusahaan

Coefficients $^{\mathbf{a}}$

\begin{tabular}{lllr}
\hline Model & \multicolumn{2}{c}{$\begin{array}{c}\text { Standardized } \\
\text { Coefficients }\end{array}$} & \\
\hline & \multicolumn{2}{c}{ Beta } & Sig. \\
\hline 1 & (Constant) & & .000 \\
\cline { 2 - 3 } & JRDD & -.041 & .788 \\
\cline { 2 - 3 } & PDKI & -.607 & .000 \\
\cline { 2 - 3 } & GCGC & -.331 & .035 \\
& SRDI & .463 & .011 \\
\hline
\end{tabular}

a. Dependent Variable: PBV

Sumber: hasil olahan data penelitian dengan SPSS 16.0, 2014

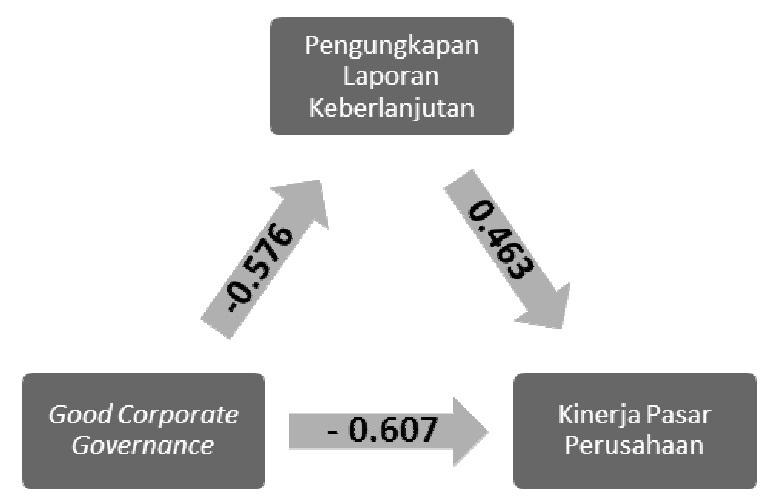

Gambar 2

\section{Diagram Jalur Hasil Pengujian Model Penelitian Kedua}

Hasil path analysis (analisis jalur) menunjukkan bahwa GCG yang diproksikan oleh proporsi dewan komisaris independen dapat berpengaruh langsung terhadap kinerja pasar perusahaan dan dapat juga berpengaruh tidak langsung yaitu ke pengungkapan laporan keberlanjutan terlebih dahulu baru kemudian ke kinerja pasar perusahaan. Besarnya pengaruh langsung adalah -0.607 , sedangkan besarnya pengaruh tidak langsung harus dihitung dengan mengalikan koefisien tidak langsungnya yaitu
$(-0.576) \times(0.463)=0.2667$. Hal ini berarti hipotesis ketiga diterima karena pengungkapan laporan keberlanjutan terbuktimampumemediasi hubungan antara GCG dan kinerja pasar perusahaan.

Disamping itu, selain berperan sebagai variabel intervening, pengungkapan laporan keberlanjutan juga dapat berperan sebagai variabel independen terhadap kinerja pasar perusahaan karena hasil pengujian menunjukkan bahwa variabel pengungkapan laporan keberlanjutan sebagai variabel independen memiliki tingkat signifikansi yang lebih kecil dari 0.1 atau $10 \%$ yang digunakan dalam penelitian ini.

\section{Pembahasan}

\section{Pengaruh Good Corporate Governance Terhadap Kinerja Pasar Perusahaan}

Berdasarkan hasil pengujian terhadap $\mathrm{H}_{1 \mathrm{a}}$, diketahui bahwa jumlah rapat dewan direksi terbukti berpengaruh terhadap kinerja pasar perusahaan sehingga hipotesis $\mathrm{H}_{1 \mathrm{a}}$ diterima. Peran dewan direksi dalam perusahaan adalah sebagai pengendali perusahaan, termasuk di dalamnya mengambil keputusan yang berkenaan dengan kegiatan operasional perusahaan, baik untuk jangka pendek maupun jangka panjang. Pengambilan keputusan ini biasanya dilakukan dengan mengadakan rapat dewan direksi. Semakin banyak jumlah rapat dewan direksi yang diadakan selama satu tahun akan meningkatkan efektivitas kinerja dewan direksi. Meningkatnya kinerja dewan direksi akan berpengaruh terhadap kinerja perusahaan. Pada dasarnya, apabila kinerja perusahaan meningkat, hal ini akan diiringi dengan meningkatnya kinerja pasar perusahaan sehingga meningkatnya jumlah rapat dewan direksi akan meningkatkan kinerja pasar perusahaan.

Hasil pengujian $\mathrm{H}_{1 \mathrm{~b}}$ menunjukkan bahwa proporsi dewan komisaris independen terbukti berpengaruh signifikan positifterhadapkinerja pasar perusahaan. Hal ini berarti semakin banyak jumlah komisaris independen dalam susunan anggota dewan komisaris perusahaan, maka kinerja pasar 
perusahaan akan semakin baik. Hasil penelitian ini didukung oleh argumen yang dinyatakan Mangel dan Singh (1993) bahwa dengan fungsinya sebagai pemeriksa dan penyeimbang dalam meningkatkan efektivitas kinerja dewan komisaris, keberadaan komisaris independen akan meningkatkan kepercayaan investor. Meningkatnya kepercayaan investor akan mendorong naiknya harga saham sehingga PBV perusahaan juga akan naik.

Pengujian yang dilakukan terhadap $\mathrm{H}_{1 \mathrm{c}}$ memperoleh hasil bahwa keberadaan governance committee tidak terbukti berpengaruh terhadap kinerja pasar perusahaan, dengan demikian $\mathrm{H}_{1 \mathrm{c}}$ ditolak. Governance committee sebenarnyabertugas membantu dewan komisaris dalam mengkaji kebijakan GCG secara menyeluruh, termasuk halhal yang berkaitan dengan etika bisnis dan tanggung jawab sosial perusahaan, sehingga pembentukan governance committee seharusnya dapat menjadi salah satu cara untuk meningkatkan efektifitas penerapan GCG pada suatu perusahaan. Namun pada kenyataannya, banyak perusahaan yang masih belum membentuk governance committee karena pembentukan governance committee tidak bersifat mandatori sehingga banyak perusahaan menganggap keberadaan governance committee tidak memiliki peran yang signifikan karena penerapan GCG masih dapat diawasi dan dikaji oleh dewan komisaris perusahaan.

\section{Pengaruh Pengungkapan Laporan Keberlanjutan Terhadap Kinerja Pasar Perusahaan}

Hasil pengujian hipotesis kedua membuktikan bahwa pengungkapan laporan keberlanjutan memiliki pengaruh yang signifikan positif terhadap kinerja pasar perusahaan. Hal ini ditunjukkan oleh koefisien regresi sebesar 4.993 dan nilai $p$ value 0.14 . Dengan demikian $\mathrm{H}_{2}$ tidak dapat ditolak.

Penerapan indeks yang memasukkan kategori saham-saham perusahaan yang telah mempraktikkan CSR oleh otoritas bursa saham di dunia membuat pelaporan tanggung jawab sosial perusahaan melalui laporan keberlanjutan menjadi senjata utama perusahaan-perusahaan dalam menarik minat para investor untuk berinvestasi sehingga pengungkapan laporan keberlanjutan memilikipengaruh yang besarterhadapkinerja pasar perusahaan. Semakin banyak item pengungkapan yang diungkapkan dalam laporan keberlanjutan, hal tersebut akan meningkatkan kualitas laporan. Meningkatnya kualitas laporan akan diiringi dengan meningkatnya kepercayaan investor terhadap perusahaan sehingga meningkatkan kinerja pasar perusahaan. Hasil ini juga didukung oleh beberapa penelitian terdahulu (Adhima 2011; Susanto dan Tarigan 2013; Burhan dan Rahmanti 2012) yang memperoleh hasil bahwa pengungkapan laporan keberlanjutan berpengaruh sigfinikan positif terhadap kinerja perusahaan.

\section{Pengungkapan Laporan Keberlanjutan Sebagai Variabel Intervening Antara Hubungan Good Corporate Governance dan Kinerja Pasar Perusahaan}

Pengujian variabel intervening dengan metode path analysis dilakukan dengan membandingkan besar koefisien jalur pengaruh langsung dengan koefisien jalur pengaruh tidak langsungnya. Untuk variabel GCG, karena hanya proksi proporsi dewan komisaris independen saja yang terbukti berpengaruh signifikan baik dalam pengujian pengaruh langsung maupun pengujian pengaruh tidak langsung, maka hanya standardized coefficients beta proporsi dewan komisaris independen yang digunakan dalam perhitungan pengaruh GCG.

Nilai -0.576 menunjukkan bahwa pengaruh GCG terhadap laporan keberlanjutan memiliki arah negatif. Hal ini berarti meningkatnya proporsi dewan komisaris independen akan menurunkan kualitas pengungkapan laporan keberlanjutan. Sebaliknya, nilai 0.463 menunjukkan bahwa pengaruh pengungkapan laporan keberlanjutan terhadap kinerja pasar perusahaan memiliki arah 
positif. Hal ini berarti meningkatnya kualitas pengungkapan laporan keberlanjutan akan meningkatkan kinerja pasar perusahaan.

Dewan komisaris independen merupakan organ perusahaan yang tidak memiliki hubungan afiliasi dengan perusahaan yang dipilih secara transparan dan independen dengan tujuan untuk mengawasi pengelolaan perusahaan. Kompensasi atas jasa yang diberikan oleh komisaris independen dibayarkandalambentukhonorarium denganjumlah yang relatif lebih besar daripada yang dibayarkan kepada komisaris perusahaan. Apabila proporsi dewan komisaris independen perusahaan cenderung besar, maka perusahaan harus mengeluarkan biaya yang lebih besar untuk membayar honorarium yang menyebabkan menurunnya laba bersih perusahaan yang dilaporkan.

Pada praktiknya, apabila hal ini terjadi perusahaan cenderung akan mengalokasikan biaya honorarium ke beban lain sehingga pelaporan yang dilakukan tidak mencerminkan keadaan yang sesungguhnya yang berdampak pada menurunnya kualitas laporan. Apabila kualitas laporan menurun, hal ini akan menurunkan kinerja pasar perusahaan karena laporan yang disajikan dianggap tidak reliable untuk digunakan dalam pengambilan keputusan berinvestasi.

\section{KESIMPULAN DAN SARAN}

\section{Kesimpulan}

Penelitian ini terbagi menjadi dua model penelitian. Model penelitian pertama menguji pengaruh GCG yang diproksikan oleh jumlah rapat dewan direksi, proporsi dewan komisaris independen, dan keberadaan governance committee serta pengungkapan laporan keberlanjutan terhadap kinerja pasar perusahaan. Model penelitian kedua menguji pengungkapan laporan keberlanjutan sebagai variabel yang memediasi hubungan antara GCG dan kinerja pasar perusahaan.

Penelitian ini dilakukan dengan mengambil 30 sampel untuk model penelitian pertama dan
29 sampel untuk model penelitian kedua dengan metode purposive sampling. Kedua penelitian memiliki populasi yang sama yaitu perusahaan yang terdaftar di Bursa Efek Indonesia pada tahun 2009 - 2012.

Hasil pengujian model penelitian pertama membuktikan bahwa GCG yang diproksikan oleh jumlah rapat dewan direksi dan proporsi dewan komisaris independen, serta pengungkapan laporan keberlanjutan sebagai variabel independen berpengaruh terhadap kinerja pasar perusahaan. Sedangkan proksi GCG yaitu keberadaan governance committee tidak terbukti berpengaruh terhadap kinerja pasar perusahaan.

Hasil pengujian model penelitian kedua membuktikan bahwa pengungkapan laporan keberlanjutan sebagai variabel intervening terbukti mampu memediasi hubungan antara GCG dan kinerja pasar perusahaan. Selain itu juga diperoleh hasil bahwa GCG dapat mempengaruhi kinerja pasar perusahaan secara langsung tanpa harus melakukan pengungkapan laporan keberlanjutan.

\section{Saran}

Peneliti menyadari bahwa penelitian ini masih jauh dari sempurna. Terdapat beberapa saran sebagai masukan bagi peneliti selanjutnya, yaitu:

Variabel GCG sebaiknya diukur dengan menggunakan skor CGPI karena skor CGPI dapat mewakili pengimplementasian GCG pada suatu perusahaan secara menyeluruh.

Variabel dewan direksi dapat menggunakan pengukuran lainnya misalnya jumlah dewan direksi atau diversitas dewan direksi. Hal ini merujuk pada penelitian yang dilakukan oleh Puteri (2013) yang memperoleh hasil bahwa jumlah dewan direksi terbukti berpengaruh positif terhadap kinerja perusahaan.

Perusahaan-perusahaan yang dipilih menjadi sampel sebaiknya tidak hanya partisipan ISRA. Hal ini bertujuan untuk menghindari keterbatasan data pada penelitian yang akan dilakukan di masa mendatang. 


\section{DAFTAR PUSTAKA}

Adhima, M. Fauzan. 2011. Pengaruh Pengungkapan Sustainability Report Terhadap Profitabilitas Perusahaan. Jurnal Ilmiah Mahasiswa, 1(1), 133-155.

Alfia, R.P. 2013. Pengaruh Struktur Corporate Governance Terhadap Pengungkapan Corporate Social Responsibility Dalam Sustainability Report. Skripsi tidak diterbitkan. Universitas Diponegoro, Semarang.

Anggraini, Siska. 2014. Pengaruh Karakteristik Perusahaan dan Good Corporate Governance Terhadap Pengungkapan Sustainability Report. Skripsi tidak diterbitkan. Universitas Negeri Lampung, Lampung.

Arifin, H.Ikhwanul. 2010. Hubungan Antara Mekanisme Good Corporate Governance (Komisaris Independen, Kepemilikan Manajerial, Kepemilikan Asing, Hutang, dan Kualitas Audit) dengan Kinerja Saham. Skripsi tidak diterbitkan, Universitas Diponegoro, Semarang.

Brigham, E.F dan Houston, J.F. 2009. DasarDasar Manajemen Keuangan. Buku 1 (Edisi 10). Jakarta: Salemba Empat.

Burhan, Annisa dan Rahmanti, Wiwin. 2012. The Impact of Sustainability Reporting on Company Performance. Journal of Economics, Business, and Accountancy Ventura, 15(2), 257-272.

Caesari, A.Putri. 2013. Analisis Pengaruh Good Corporate Governance Terhadap Kinerja Keuangan dan Harga Saham Perusahaan yang Masuk ke Dalam Pemeringkatan Corporate Governance Perception Index. Skripsi tidak diterbitkan. Institut Pertanian Bogor, Bogor.

Chariri, A dan Nugroho, F.Aji. 2009. Retorika Dalam Pelaporan Corporate Social Responsibility: Analisis Semiotik Atas
Sustainability Reporting PT Aneka Tambang, Tbk. Paper dipresentasikan pada acara Simposium Nasional Akuntansi XII.

Fathoni. 2014. The Effect of Good Corporate Governance Mechanism, Financial Distress On Earning Management Behavior: Empirical Study In Property and Infrastucture Industry In Indonesian Stock Exchanges. Jurnal Ekonomi, 22(1), 1-16.

Ghozali, I dan Chariri, A. 2007. Teori Akuntansi (Edisi 3). Semarang: Badan Penerbit Universitas Diponegoro.

Ghozali, Imam. 2011. Aplikasi Analisis Multivariate Dengan Program IBM SPSS 19 (Edisi 5) Semarang: Badan Penerbit Universitas Diponegoro.

GRI. 2006. Pedoman Laporan Keberlanjutan G3. Diunduh tanggal 18 Oktober 2014, http:// www.globalreporting.org.

Hadiwijaya, R.C. 2013. Pengaruh Intellectual Capital Terhadap Nilai Perusahaan Dengan Kinerja Keuangan Sebagai Variabel Intervening. Skripsi tidak diterbitkan. Universitas Diponegoro, Semarang.

Idah. 2013. Peran Corporate Governance dan Karakteristik Perusahaan Terhadap Pengungkapan Sustainability Report Pada Perusahaan Terdaftar di BEI Periode 2010-2011. Skripsi tidak diterbitkan. Universitas Negeri Semarang, Semarang.

Jensen, Michael.C dan Meckling, William.H. 1976. Theory of the Firm: Managerial Behavior, Agency Costsand Ownership Structure. Journal of Financial Economics, 3, 305-360.

Komite Nasional Kebijakan Governance. 2006. Pedoman Umum Good Corporate Governance Indonesia. Jakarta: Komite Nasional Kebijakan Governance. 
Natalia, Ria dan Tarigan, Josua. 2014. Pengaruh Sustainability Reporting Terhadap Kinerja Keuangan Perusahaan Publik dari Sisi Profitability Ratio. Business Accounting Review, 2(1), 111-121.

Nurdin, Emilia dan Cahyandito, M.Fani. 2006. Pengaruh Kualitas Pengungkapan Sosial dan Lingkungan dalam Laporan Tahunan Perusahaan terhadap Reaksi Investor. Tesis tidak diterbitkan. Universitas Padjajaran, Bandung.

Nurmalasari, Indah. 2012. Analisis Pengaruh Rasio Profitabilitas Terhadap Harga Saham Emited LQ45 yang Terdaftar di Bursa Efek Indonesia Tahun 2005-2008. Jurnal Akuntansi dan Keuangan.

Phillips, J.M dan Gully, S.M. 2011. Organizational Behavior: Tools for Success. Cengage Learning.

Purba, E.S. 2011. Analisis Pengaruh Good Corporate GovernanceI Terhadap Kinerja Keuangan Perusahaan Perbankan yang Terdaftar di Bursa Efek Indonesia. Skripsi tidak diterbitkan. Universitas Sumatera Utara, Medan.

Puteri, P.A.W.A. 2013. Karakteristik Good Corporate Governance dan Kinerja Perusahaan Manufaktur. Skripsi tidak diterbitkan. Univesitas Udayana, Bali.

Ramdani dan Yadnyana. 2013. Pengaruh Good Corporate Governance dan Kinerja Keuangan Pada Harga Saham Perbankan yang Terdaftar di Bursa Efek Indonesia Tahun 2009-2011. Skripsi tidak diterbitkan. Universitas Udayana, Bali.

Ratnasari, Yunita. 2010. Pengaruh Corporate Governance Terhadap Luas Pengungkapan Tanggung Jawab Sosial Perusahaan di dalam Sustainability Report. Skripsi tidak diterbitkan, Universitas Diponegoro, Semarang.
Retno, Reny Dyah dan Priantinah, Denies. 2012. Pengaruh Good Corporate Governance dan Pengungkapan Corporate Social Responsibility Terhadap Nilai Perusahaan. Jurnal Nominal, 1(1), 84103.

Riswari, D.Ardana. 2012. Pengaruh Corporate Social Responsibility Terhadap Nilai Perusahaan dengan Corporate Governance sebagai Variabel Moderating. Skripsi tidak diterbitkan, Universitas Diponegoro, Semarang.

Said, R.Zainuddin dan Haron, H. 2009. The Relationship between Corporate Social Responsibility Disclosure and Corporate Governance Characteristics in Malaysian Public Listed Companies. Social Responsibility Journal, 5(2), 212-226.

Soelistyoningrum, J.Nur. 2011. Pengaruh Pengungkapan Sustainability Report Terhadap Kinerja Keuangan. Skripsi tidak diterbitkan. Universitas Diponegoro, Semarang.

Sugiyono. 2010. Metode Penelitian Kuantitatif, Kualitatif, dan R\&D. Bandung: Alfabeta.

Susanti, Susi. 2013. Pengaruh Good Corporate Governance Terhadap Corporate Social Responsibility Pada Perusahaan Cosmetics and Household. Jurnal Ilmu dan Riset Akuntansi, 1(1), 152-167.

Susanto, Y.K.,\& Tarigan, J. 2013. Pengaruh Pengungkapan Sustainability Report Terhadap Profitabilitas Perusahaan. Business Accounting Review, 1(1), 1-20.

Tjondro, David dan Wilopo, R. 2011. Pengaruh Good Corporate Governance Terhadap Profitabilitas dan Kinerja Saham Perusahaan Perbankan yang Tercatat di Bursa Efek Indonesia. Journal of Business and Banking, 1(1), 1-14.

Tryfino. 2009. Cara Cerdas Berinvestasi Saham (Edisi 1). Jakarta: Transmedia Pustaka. 
UU Nomor 40 Tahun 2007. 2007. UndangUndang No.40 Tahun 2007 tentang Perseroan Terbatas. Jakarta: Departemen Keuangan.

Waryanto. 2010. Pengaruh Karakteristik Good Corporate Governance Terhadap Luas Pengungkapan Corporate Social Responsibility di Indonesia. Skripsi tidak diterbitkan. Universitas Diponegoro, Semarang.

Wicaksana, Adityas. 2010. Pengaruh Intellectual Capital Terhadap Pertumbuhan dan Nilai Pasar Perusahaan Pada Perusahaan Perbankan yang Tercatat di Bursa Efek Indonesia. Skripsi tidak diterbitkan. Universitas Diponegoro, Semarang.
Widianto, H.Suryono. 2011. Pengaruh Profitabilitas, Likuiditas, Leverage, Aktivitas, Ukuran Perusahaan, dan Corporate Governance Terhadap Praktik Pengungkapan Laporan Keberlanjutan. Skripsi tidak diterbitkan. Universitas Negeri Semarang, Semarang.

Widyati, M.Fransisca. 2013. Pengaruh Dewan Direksi, Komisaris Independen, Komite Audit, Kepemilikan Manajerial, dan Kepemilikan Institusional Terhadap Kinerja Keuangan. Jurnal Ilmu Manajeme, 1(1), 234-249. 